\title{
UN SECURITY COUNCIL REFORM AND GLOBAL SECURITY
}

\author{
Katak B. Malla*
}

\section{INTRODUCTION}

This article raises a question concerning the ongoing UN Security Council reform and global security, which is: Can global security be realized by increasing the number of permanent members of the Security Council from the present five to fifteen or more? The present author argues that changing the number of the permanent members in the Security Council does not help to ensure global security. It is claimed that the Security Council per se was created as a neo-colonial superstructure after World War II, and in this structure it is apparent that the UN member States have surrendered their position to the Security Council, conferring power and privilege on the permanent member States. ${ }^{1}$ Under the aegis of the principle of equal yet differentiated responsibility, the economically and militarily weak member States of the UN have become subordinate to powerful States; as a result, weaker States are in a colonized situation whereby they are unable either to determine what constitutes threats to peace and security on their own terms and conditions, or their genuine concerns are not taken into full consideration by the more powerful States in determining global security and social justice. Since the Security Council is empowered to determine threats endangering international peace and security, and to respond to such threats including through the military use of force, the position of the permanent members of the Council has not only become that of both judge and jury; they are, furthermore, acting as both legislator and administrator. There is also no international legal arrangement for the judicial review of the actions of the Council. In such a situation, it is obvious that the individual interests of the powerful member(s) prevail over the general international community interest in the decision-making of

\footnotetext{
* Doctor of Laws, Stockholm University, Sweden, and Research Fellow at the Department of Law, Stockholm University, Sweden: Teaching the legal aspects of the Trans-boundary Water Basins (Masters Course of Environmental Law Across State Borders) and currently running a research project "Global Climate Security and Modernization of International Law".

1 It is well known that the United States and (the former Soviet Union) Russia would not have accepted the creation of the United Nations without the veto privilege.
}

Asian Yearbook of International Law, Volume 12 (B.S. Chimni et al., eds.)

(C) 2007 Koninklijke Brill NV. Printed in The Netherlands, pp. 31-56. 
the Security Council. Consequently, the Security Council has not only failed in reaching consensus to carry out the primary responsibility conferred upon them, but has also lost its legitimacy to represent the international community of nations. The principle here is that any national or international legal authority can surrender its legitimacy when it fails to fulfil commitments and/or the mandated responsibility.

The present author recognizes that since the vested economic and military interests of powerful State(s) may constitute constraints to common global security, these issues are relevant to discussion in international law; it is further suggested that as long as the existing international economic and military disparity remains, global security through the existing or an enlarged Security Council may not be realized. As there is a serious concern expressed in the UN reform agenda about the interest of the world's peoples, ${ }^{2}$ it is recommended that the whole idea of global security be perceived and implemented in consistency with threats involving international socioeconomic, political, and environmental issues, rather than national security threats as perceived by individual States.

As an alternative to the official UN reform agenda, a Super General Assembly should be established, consisting of the democratic member States of the existing UN General Assembly. The proposed Super General Assembly could be an appropriate body of the UN to generate international law and order, especially by separating the current dual functioning of the Security Council as both legislator and administrator into discrete entities. In addition, instead of allowing the Security Council to act as judge and jury, the role and functions of the International Court of Justice (ICJ) need to be strengthened through the universal recognition of the compulsory jurisdiction of the Court. The present author recognizes that the overall arrangement of the $\mathrm{UN}$ is a legitimate international endeavour. However, there is no doubt that the UN needs to be enhanced as a third-generational international institution.

Readers will find the main question posed at the beginning of this article discussed along with suggestions in the following order: initially, a short description of the

2 The UN Secretary General proposed a reform strategy to the General Assembly on 25 March 2005, giving equal weight to development, security, and human rights. He urged Member States to establish a Peace-Building Commission to help countries make the transition from war to lasting peace, including a Democracy Fund to provide funding and technical assistance to countries seeking to establish or strengthen their democracy. The Secretary General has also recommended a system of Councils, covering (a) international peace and security, (b) economic and social issues, and (c) human rights. Among these, the first two of these Councils already exist and the third, as suggested by the Secretary General, is the creation of the Human Rights Council, which he suggests should be smaller than the present Commission; the new Council should be "elected directly by a two-thirds majority of the General Assembly." As regards the Secretariat itself, the Secretary General has acknowledged that it must be made more flexible, transparent and accountable in serving the priorities of Member States, and the interests of the world's peoples. Following the Secretary General's report, the UN General Assembly released, on 5 August 2005, a third draft outcome document for the forthcoming World Summit, aiming to strengthen the UN, recognizing the freedoms from want and fear as well as the freedom to live in dignity. See Press Release SG/SM/9770, GA/10335, ORG/ 1438, based on the text of the UN Secretary General's statement to the General Assembly, in New York on 21 March 2005. 
"Official Reform Agenda" of the UN will be given, followed by a discussion on the existing UN "Security Council Regime". There is also a thorough discussion of vital issues entitled "Security on Whose Terms?". The article further provides an alternative proposal to the official UN reform agenda, entitled "A Third-Generational International Institution", which is elaborated under the following subheadings: "A ThirdGenerational Super General Assembly (3G Assembly)"; "A Third-Generational International Court (3G Court)"; and "Implementation of International Law". The article concludes with suggestions.

\section{OFFICIAL REFORM AGENDAS}

Marking the UN's sixtieth anniversary in September 2005, more than 150 heads of State and government signed a deal to re-shape the world body in order to meet the challenges of the twenty-first century. This was done in consideration of a reform strategy proposed by the UN Secretary General in the General Assembly. ${ }^{3}$ A few, yet important, outcomes of the summit meeting are as follows: 1) The Protocol of the summit meeting obliges intervention in cases of genocide, acknowledging that there is an international responsibility to protect people from genocide, war crimes and ethnic cleansing; 2) Terrorism is condemned "in all its forms and manifestations, committed by whomever, wherever and for whatever purposes". However, the meeting failed to settle on a definition of terrorism. 3) The goals to combat global poverty are reaffirmed. The final document of the summit meeting decided to establish a new Peace-Building Commission to help countries make the transition from war to peace and to set up a new powerful Human Rights Council, ${ }^{4}$ replacing the Human Rights Commission. Modalities, powers and functions of the proposed institutions are the matter of negotiations among States.

In his reform strategy, the UN Secretary General has urged Member States to make the Security Council more nearly representative of the international community as a whole, based on the geo-political realities of the present time. He has suggested that the Security Council should make clear "in a resolution, the principles by which it intends to be guided when deciding whether or not to authorize the use of force". Apart from the proposal to increase the number of permanent members in the Security Council, the UN's reform proposals include changes in the Council's procedures and working methods, such as regular rules of procedure, a greater number of public meetings, and other steps to render the Council more transparent and accountable. These issues require no changes in the UN Charter and can be implemented by a

\footnotetext{
${ }^{3}$ Ibid.

4 The UN General Assembly has voted overwhelmingly to create the Human Rights Council (170 members of the 191 of the General Assembly voted, and only three abstained). Israel, the Marshall Islands and Palau joined the US in voting against the motion. The (47-member) UN Human Rights Council will replace the (53-member) UN Human Rights Commission. The new council will comprise members who are elected by secret ballot by an absolute majority of the General Assembly.
} 
decision of the Council itself. However, an amendment to the Charter is required in order to increase the number of permanent members on the Security Council.

\subsection{Comments on the official agenda}

The above-mentioned changes and proposed changes in the reform strategy of the UN Secretary General are important yet, in my opinion, do not go far enough in order to ensure global security threatened by political, economic, resource- and environment-related conflicts at local, national and international levels. In the absence of substantial and overall changes in the UN system, particularly the need for the existing international system of rule of power to be replaced by the rule of law, the serious problems of the world cannot be resolved. These problems are threatening global security and resulting in social injustice, including an increase in poverty, a decline in human dignity, and human rights violations inflicted not only by the world's dictatorial regimes but also by democracies. ${ }^{5}$

From the few successes and the many failures of the UN activities one can draw the conclusion that "social justice" is a precondition for durable "peace" and that a lack of management of the international legal order is leading to "global injustice", a source of major conflicts and thus destabilizing global security. ${ }^{6}$ The political problem of the present world is that there exists a worldwide domination by a handful of States, in terms of military, economic, and technological strength. The economic problem, combined with political and legal problems, is that there is over-exploitation of the world's resources - the accumulation of wealth by a few, resulting in the deprivation of basic living conditions of others, and unsustainable development which in turn threatens common security in terms of resources and environment.

Therefore, there is a need for the UN reforms to focus on the core issues such as the establishment and management of an international rule of law, as opposed to the existing order of power through domination; proper observation of the rules, as opposed to the selective respect of rules; and compulsory peaceful settlement of international disputes by adjudication or arbitration, as opposed to optional judicial settlement. In addition, the UN reforms need to focus on the fundamental question: how the very idea of security is conceived as well as implemented. Unlike a monolithic discourse of normative national security, global security needs to be implemented in consistency with resource, environment and climate securities.

\footnotetext{
5 While the Iraqi dictator, Saddam Hussein, was ousted by the intervention of the United States and its allies, it is nevertheless dictatorial for anyone to wage war against anyone without the collective decision of the UN Security Council. Even if dictators may indeed be toppled by force, there are still many dictators in the world.

${ }^{6}$ For example, the end of apartheid in South Africa provided a sense of justice not only to the people of South Africa but also to the world community, just as the end of slavery and decolonization provided a sense of justice to the world. Foreign occupations or dominations still remain a source of conflicts in the world.
} 


\section{SECURITY COUNCIL REGIME}

The international institutional order, established by the UN in 1945, recognizes sovereign equality of States based on the respect of international law, but this international order has also established a hierarchy of five permanent members of the Security Council. More often than not, the interests of these States influence the international order. The five permanent members of the Security Council, i.e., the United States, the United Kingdom, China, France, and Russia, have a special yet undemocratic position in the decision-making process. The Security Council, consisting of fifteen members (five permanent and ten non-permanent elected by the UN General Assembly for two years), is responsible for the maintenance of international peace and security. The Security Council is supposed to represent the international community and fulfil its obligations on behalf of the community, as stated in Article 24 of the Charter:

In order to ensure prompt and effective action by the United Nations, its Members confer on the Security Council primary responsibility for the maintenance of international peace and security, and agree that in carrying out its duties under this responsibility the Security Council acts on their behalf.

Article 24 has conferred the powers of the Security Council; however, its legitimacy to act on behalf of the international community is an unresolved issue of international law. An unsuccessful attempt was made to overcome issues concerning the lack of representation and legitimacy of the Security Council by amending Article 23, which enlarged the membership from eleven to fifteen. This amendment does not seem to have helped either to establish legitimacy or to create appropriate representation of the community of nations in the Council since there is an ongoing discussion about enlarging the Council. It is conformed by suggestions made by the UN Secretary General Kofi Annan to make the Security Council "more representative of the international community as a whole, based on the geo-political realities of the present time".

According to Article 41 the Security Council may decide what measures involving the use of armed force are to be employed to give effect to its decisions, and it may call upon the Members of the United Nations to apply such measures. All Members of the United Nations are obliged, in Article 43(1), to observe the Security Council decisions in order to maintain international peace and security.

\subsection{Judge and jury as well as legislator and administrator}

When it comes to the question of the determination of threat and security according to Article 39 of the Charter, the Security Council is authorized to determine the existence of any threat to peace, breach of peace, or act of aggression. The Council is held responsible for making recommendations or deciding what measures to take in order to restore international peace and security. This means that the Council has 
the power to act as a jury in determining threats, and also the responsibility to act as a judge in taking action.

In addition to this dual role, there is another legal absurdity that, on the basis of Chapter VII of the Charter, the Council is acting not only as legislator and administrator, but also as a court, determining the financial liability of the adversary party, i.e., in the case of Iraq's intervention in Kuwait the Council determined the financial liability of Iraq. ${ }^{7}$ This exercise seems clearly to be against the general principle of law: not to be judge of one's own actions, as well as to distinguishing the different roles of jury and judge.

\subsection{Global dictatorship or tyranny of vetoes}

There is yet another legal problem arising out of the principle of equal but differentiated responsibility: the decision making in the Security Council is clearly dictatorial, resulting in international lawlessness, ${ }^{8}$ if not the tyranny of Orwell's Animal Farm. ${ }^{9}$ Despite the fact that Article 27 of the Charter was amended, providing that "decisions of the Security Council on procedural matters shall be made by an affirmative vote of nine members (formerly seven) and on all other matters by an affirmative vote of nine members (formerly seven), including the concurring votes of the five permanent members", it must be noted that the five permanent members are empowered to void any Security Council resolution, irrespective of the supporting majority. This is known as veto power, exercised when any permanent member enters a "negative" vote; an abstention vote allows the measure to pass. The veto power has virtually undermined the strength and authority of the UN Security Council.

Among the permanent members of the Security Council, the US is the most powerful at the moment, and either dominates the decision-making process in the Council, or simply ignores the defined rules of the Charter. ${ }^{10}$ In the present international order where vested national interests are vital, it is understandable that the US is able to use or misuse the UN. The US also dictates the reform agenda, the UN being financially dependent upon the United States.

\footnotetext{
7 Harper, K., "Does the United Nations Security Council have competence to act as court and legislature?", 27 New York University Journal of International Law and Politics (1994), at 1-2-157. 8 Sands, P., Lawless World Making and Breaking Global Rules, (London: Penguin Books Ltd., 2005).

9 George Orwell's Animal Farm is an allegory of betrayal, power and corruption. When the downtrodden animals of Manor Farm overthrow their master Mr. Jones and take over the farm themselves, they imagine it is the beginning of a life of freedom and plenty. But as the cunning, ruthless élite among them starts to take control, the other animals find themselves hopelessly ensnared as one form of tyranny is gradually replaced by another. Orwell, G., Animal Farm (London: Penguin Books Ltd., reprint, 2003).

${ }_{10}$ The United States is often criticized for using its veto power at the Security Council in favour of Israel.
} 


\subsection{Where is the Security Council heading after Iraq?}

The invasion of Iraq, and its regime change, by the US and the UK without authorization from the Security Council illustrates how powerful States act or are likely to act in order to defend their interests. The role of the other permanent members of the Council, since 1991, in the case of Iraq indicates how they will be acting or reacting in similar scenarios in the future, yet there remain a few questions unanswered: What would have happened if France had been the invader of Iraq without the consent of the Security Council?; What could have been the reaction of the US against France in such a case?; Would the UK and the other pro-invasion States have supported the French invasion on Iraq had the US been in opposition to France? Will the norm and practice established by the US and the UK in the case of Iraq allow Russia or China to take unilateral action at their will? Answers to these questions are important when shaping a reformed Council prepared to take collective security actions. Where we go from Iraq is a challenge to the collective security. ${ }^{11}$

\subsection{Does the international community of civilized nations exist?}

In a society of civilized nations, which is often claimed to exist, one has to ask why only rich and powerful States should be eligible to become permanent members of the Security Council.

As opposed to the mandate of Article 24 of the Charter, the permanent members of the Security Council have clearly used their positions as a neo-colonial superstructure, exercising military powers rather than establishing democratic norms. Being the inventors and proliferators of nuclear weapons, the permanent members of the Council are responsible for creating a nuclear balance of terror. In addition, they are the largest producers and traders of conventional weapons, fuelling armed conflicts in many regions of the world - itself indeed a threat to global security. Militarily, technologically and economically, the permanent members of the Council are themselves the world's competing powers and are concerned about their respective spheres of influence in order to control resources and other people's lives. They are also industrial powers responsible for the emission of greenhouse gases, leading to a global climate change resulting in global environmental insecurity. The States aiming to become permanent members of the Council, e.g., Japan, Germany, Brazil, India, and perhaps South Africa (and the European Union), are also industrial States contributing a major share to global environmental harm. None of the economically poor and militarily weaker States are seeking permanent membership of the Council. Some poor States are being labelled as "failed States" and are therefore the target of control and domination, if not intervention, by powerful States.

11 Jacobsson, M., "The use of force and the case of Iraq", in Amneus, D. and K. Svanberg-Torpman (eds.), Peace and Security Current Challenges in International Law (Lund, Sweden: Studentliteratur, 2004), at 373-407. 
Over the past sixty years, with the enormous power and wealth of the permanent members of the Security Council, they could and should have resolved many of the world's problems, especially by promoting an international legal order. Instead, the Security Council itself has become a source of rather than a solution to the problems, mainly because of the lack of consensus deriving from their vested interests. Given their dominant positions in the Security Council, none seems in favour of a more democratic UN, which would entail their relinquishing their power of veto. As the Security Council reform process in itself seems complex, one might wonder what legitimacy the Security Council would have if the reform did not take place as is aimed for, and if an expansion of the permanent members failed.

Criticisms of legitimacy seem strongest where the Security Council purports to speak for the global community in making declarations and imposing sanctions on States. However, some critics of legitimacy look rightly beyond the Security Council's decision-making process and beyond whether the Security Council is merely acting in accordance with its legal competence. Thomas Franck suggests that it is important to see whether or not the Security Council acts in accordance with general principles of fairness. ${ }^{12}$ He argues that there must be determinacy, consistency and coherence in a rule-based system. In addition, a deeply common-sense question is: How can a few powerful States represent the whole international community of weak and under-developed States whose interests are incompatible with the interest of the permanent members? This is a challenging legal and political question to be answered appropriately for the establishment of the twenty-first century international legal order to take place.

\section{SECURITY ON WHOSE TERMS?}

The present international security order, which has its roots in the 1648 Treaty of Westphalia, recognizes the sovereign equality of States as the basis of international law. This de facto legal order has been operating with no central authority enforcing it directly, but has been indirectly imposed based on a balance of power. According to the balance of power theorists, whether it is the issue of resource sharing or peace and security, the international order is maintained not through international law or organizations, but by virtue of détente, by which the ambitions of one power are moderated by the countervailing power of its counterparts. ${ }^{13}$

The author suggests that the balance of power mentality, even in its present form, is essentially neo-colonial, under which States struggle for control over territory in order to control the resources within that territory. Instead of the balance of power,

${ }^{12}$ Franck, T, The Power of Legitimacy among Nations (New York: Oxford University Press, 1990); Franck, T, "Legitimacy and the democratic entitlement", in Fox, Gregory H. and Brad R. Roth, Democratic Governance and International Law (Cambridge: Cambridge University Press, 2000).

${ }_{13}$ Kissinger, for example, is one of the staunchest supporters of the balance of power theory. See Kissinger, H., A World Restored: The Politics of Conservatism in a Revolutionary Era (London: Gollancz, 1974). 
it is asserted that peace and security can best be guaranteed by international law and organizations through the establishment of a meaningful international institutional order built upon consent and respect for such laws. The author believes, in line with the institutionalists and critical security studies' view, one must cultivate a more questioning attitude towards the whole framework. This questioning must cover not only why States quarrel over resources, but also the ways in which peace and security are implemented and conceptualized. ${ }^{14}$ In contrast to the fixed knowable world of the realists, ${ }^{15}$ and in line with the post-Modernist interpretation of reality, the author would subscribe to the principle of coexistence. In philosophical terms, it emphasizes the creative instincts of States or individuals seeking to share the earth's resources, rather than seeking primarily to satisfy one's own wants. An integrated approach to international law and institutions, it is being suggested, should be used to define global security, the rule of law and social justice. The main facts supporting these arguments are as follows.

\subsection{Colonial tendencies of powerful States}

The first fact is based upon the legacy of States' struggles for power to control over territory and its resources, an integral part of the history of nation-States. The history of colonial control over the world's natural resources is clear: "from 1815 to 1914 European direct colonial domination, especially by Britain and France expanded from about 35 per cent of the earth's surface to about 85 per cent of it". ${ }^{16}$ Writing in the nineteenth century in support of colonization, Westlake argued that the "regions of the earth designated as uncivilized ought to be annexed or occupied by advanced powers." 17 The struggle for control over territory in order to control the resources remained the historical legacy of colonial times. In the present world, this is illustrated through China's occupation of Tibet, India's annexation of Sikkim, Israel's occupation of Palestine, and the recent US-UK occupation of Iraq. The

\footnotetext{
14 In general, there seem to be three schools of thought on security: 1) the traditionalists (also known as the normative), who wish to maintain a largely military focus; 2) those moving beyond the traditionalists, who wish to broaden the range of issues on the security agenda; 3 ) the proponents of critical security studies, who wish to cultivate a more questioning attitude to the whole framework in which security is not only conceptualized, but how it is initiated. Among these three schools of thought there may be both overlapping and contradictory ideas. However, there is a growing awareness among experts for the necessity to rethink the concept of security. See Buzan, B, "Rethinking security after the Cold War", 32 NJIS (1997), at 5-28.

15 The political science approaches are as follows. While the Realists see a fixed and knowable world, the post-Modernists see the possibility of endless interpretations of the world around them... there are no constraints, no fixed meaning, no secure grounds, no profound secrets, no financial structure or limits of history... there is only interpretation... History itself is grasped as a series of interpretations imposed upon interpretations - none primary, all arbitrary (see Baylis, J., Globalization of World Politics (Oxford: Oxford University Press, 1998), at 193-211, 205).

16 See more in Edward Said's Orientalism (London: Penguin Books Ltd., reprint, 2003), at 41.

17 Westlake, J., The Principles of International Law (Cambridge: Cambridge University Press, 1894).
} 
consequence of this legacy is that direct control by the advanced powers over the less-advanced States has been transformed into a broad social and economic influence.

This transformation can be seen in the establishment of the UN Security Council, which has assumed the responsibility of representing the whole international community in terms of maintaining peace and security. The five permanent members adopted this role. The UN Charter dealt with the colonial issues through the Trusteeship Council, recognizing the right of self-determination. At the same time, the Security Council seemed to serve the same functions and perpetuate the essence of the colonial superstructure. As a result, even as the Trusteeship Council was actively promoting the decolonization of Africa and Asia, the power of the advanced powers was transformed into a more sophisticated means of social control. ${ }^{18}$ These spheres of influence of the permanent members of the Security Council were vividly illustrated by the Cold War and its continuation of resource competition and control over the newly independent developing States.

At the Bandung Conference in 1955, the newly independent States held a conference defining the principles of peaceful coexistence among States and of remaining non-aligned in the Cold War. Almost all of these decolonized States (especially in Asia) had achieved self-determination, but economic and political independence from the former Western empires was incomplete. Yet again, they were forced to confront a configuration of powers that demanded acquiescence, in the new bipolar Cold War form, from either the United States or the Soviet Union. By the early 1990s the United States had emerged as the unipolar power in terms of political and economic influence, backed up by military might. However, from the perspective of the decolonized States, the interests of the other four permanent members of the Security Council still dominate their resource management decisions.

\subsection{Unequal powers and treaties}

The second fact supporting my arguments is that power differentiations among States determine the terms of treaties. The UN Charter itself illustrates this recognition of the privileges of power assumed by the permanent members of the Security Council. This is dramatically highlighted by the 1970 Nuclear Non-Proliferation Treaty (NPT). Instead of prescribing the complete elimination nuclear weapons, the NPT recognized the privilege of the "Nuclear Club", that is, for those States that already had nuclear capabilities to possess weapons of mass destruction. The fact that the NTP denied the access of only some States to these weapons shows the power differentiation that permeates most, if not all, aspects of international issues. Clearly, if the non-proliferation of weapons of mass destruction were the true aim of the treaty, it would first have focused on the elimination of all existing weapons and simul-

18 The Trusteeship Council administered the UN's trust territories. The Council suspended its activities in 1994 when the last of the trust territories, Palau, in the south Pacific, became independent. The Council, made up of the five permanent Security Council members, have agreed to meet as required. 
taneously restricted all other states from acquiring such weapons. If there were to be a truth-in-labelling law applied to the NPT, it should have been entitled the Nuclear Non-Proliferation (to States the Nuclear Club Does Not Trust) Treaty. As well, the hesitancy of the ICJ to make an outright pronouncement on the legality or illegality of the threat or use of nuclear weapons ${ }^{19}$ suggests that the judges are inclined to abide by the status quo and the wishes of the Nuclear Club.

\subsection{Neo-colonial trade and economic order}

The third fact supporting my arguments is that the present-day multinational (or transnational) corporations are the new faces of the old colonial instruments of economic control, serving the same functions as did the Dutch, French, Portuguese and British East India companies until the nineteenth century. Those who perceive these new faces differently have only to examine in whose interests treaties establishing international trade and financial institutions were negotiated: those of rich or poor States. The new trade and economic order and the multinational corporations are, according to critics of neo-liberal economics, the new rulers of the world, ${ }^{20}$ nourished by the rich and advanced powers and backed by their economic and trade institutions, i.e., the World Bank, the IMF, and the WTO. This means that a powerful State can easily wield undue influence over its weaker counterpart. In this unequal partnership between the rich/advanced and poor/less advanced, it is obvious that the advanced powers reap most of the benefits. Furthermore, there is the degradation of the environment from the extraction of resources and its adverse impact on the local populations, mostly by displacement. ${ }^{21}$ As was the case in colonial times, there may be an insignificant percentage of the local population benefiting from these multinational companies' activities. Overall, however, the present global economic order, in which States seem essentially no longer to have actual borders, labour and income are subject mostly to global managers' governance. In this inevitable process of economic privatization, there is direct intervention in the affairs of developing countries by advanced powers, through structural adjustment programmes and the like. In such a situation, the prospect of economic self-determination is, for the developing States, grim.

Every step towards economic development, especially industrial development, has consequences that include social and economic injustice, and environmental

\footnotetext{
19 Advisory Opinion of the ICJ concerning the Legality of the Threat or Use of Nuclear Weapons, 8 July 1996, General list No. 95. "Had the ICJ focused on the applicability of general principles of international law, it may have reached a conclusion more consonant with common sense and natural law: namely, the illegalities of the threat or use of nuclear weapons". See Mahmoudi, S., "International Court of Justice and nuclear weapons", 66 Nordic Journal of International Law (1997), at $77-100$.

20 Pilger, J., The New Rulers of the World (London/New York: Verso, 2003).

${ }^{21}$ Roy, A, The Greater Common Good, see <http://www.narmada.org/gec/gec.html> (accessed 10 December 1999).
} 
degradation. This holds true irrespective of distinctions between developing countries past or present, e.g., nineteenth-century Britain as compared with twentieth-century India. For more than 150 years, economic development models have rotated around two paradigms: free market capitalism, and centrally planned socialism. Both are predicated on extracting the maximum use from natural resources and expanding the frontiers of science to facilitate consumption. ${ }^{22}$ In the process of the deification of economic development, priority is given to the exploitation of shared natural resources over their protection, prime examples being the lack of political will among many States to implement the 1997 Kyoto Protocol of the 1992 Climate Change Convention. Parallel to this are the phenomena of economic development aid, which serves as an instrument to maintain the status quo in favour of the advanced powers. ${ }^{23}$ Similarly, fora for adjusting the rules of economic co-operation and international trade are often used as a cover to secure advantages for States or blocs of States, while restricting the trade of other States via threats of retaliatory tariffs barriers; one of many examples is that the arms trade is not included in the negotiation under the auspices of the $\mathrm{WTO}^{24}$ and another is the failure of negotiations concerning agricultural subsidies in the developed world and the impact of this failure on developing States. ${ }^{25}$

\subsection{Recognition of sub-state entities}

The fourth fact is the need for recognition of sub-state rights, specifically, the community rights of people with regard to their resources and the environment in which they live. The sub-state groups are the human communities that mediate between an individual and States. Over the course of the past thirty years, community rights have been recognized by international law in the areas of both human rights and environmental protection. It is noteworthy that the UN Johannesburg Summit (building on earlier works of the Stockholm 1972 and Rio de Janeiro 1992 Summits), for all its limitations, revealed an ongoing concern; its detailed declarations on matters dealing with the environment, famine, the gap between advanced and developing

\footnotetext{
22 See, for example, McIntosh, M., et al (eds.), Corporate Citizenship (London: Financial Times, Pitman Publishing, 1998), at 96.

23 Hans J. Morgentahu, in his book Politics Among Nations: The Struggle for Power and Peace (New York: Alfred A. Knopf, Fifth Edition, Revised, 1978) explains the way in which powerful States are concerned to keep the status quo intact against any change threatening their establishment; how one government supports another with bribes in the name of aid [to maintain the status quo], but beyond that he is doubtful that activities such as economic aid have a useful purpose though such beneficiaries belong to the hopeless group of "bum and beggar nations". See Nobel, J., "Morgenthau's struggle with power: The theory of power politics and Cold War", 12 RIS (1995), at 61-85.

24 Arms trade constitutes the major share of the world trade, yet it does not fall within the purview of the WTO.

25 WTO Ministerial talks at Cancun, December 2003.
} 
countries, health and human rights, suggest the emergence of a collective theme of community rights. ${ }^{26}$

Unlike nation-States, sub-state community relationships with nature have been, and still remain, generally cooperative. This factor emphasizes the themes of community rights, e.g., the water rights of indigenous populations, and the rights of minorities, women, and children. At this point it is absolutely necessary to make a distinction between the interests of the communities of people (whom the state claims to represent) and the policy of States (which more often than not contradicts these said interests), i.e., the community interests and national interests. ${ }^{27}$ Treaties concluded by States are ostensibly negotiated based on the interests of their respective constituents. However, the politics of the earth's resource use allocation frequently becomes enmeshed with other contentious issues, aggravating tension between neighbouring countries. The struggle for power and competition for resources between States over various issues ${ }^{28}$ leads to the issue of the earth's resources being framed as one of competing national interests. ${ }^{29}$ The fact that there is a growing trend towards wider participation in the policy-making process of international watercourse use and environmental protection ${ }^{30}$ points to the existing gap (albeit narrowing) between the so-called national interest and community interests and, at the very least, that there are fundamental failings in a particular state's democratic system.

\subsection{Global security based on equity and social justice}

Finally, it is suggested that global security must be viewed and implemented in constituency with equity and social justice. This needs to be seen in connection with issues that dominate the security agenda of the international community (i.e., rights of access to food and safe water, freedom, democracy, the rule of law and human rights, the protection of the environment, and necessity for economic development, as well as security and protection against terrorism), including States, sub-States communities and individuals. In guiding a way to the world peace, it is rightly asserted that:

There can be no social justice without reducing the cost of arms; no disarmament without a peaceful method of settling irreconcilable disputes among States; no court without binding authority to resolve such disputes until States agree to give it necessary power;

26 The UN Summit held in Johannesburg in 2002. See http://www.johannessburgsummit.org/.

${ }^{27}$ Zinn, H.A., A People's History of the United States (New York: Perennial Classics HarperCollins Publishers, 2001).

${ }^{28}$ See, for example, Morgenthau, n. 23.

${ }^{29}$ In Egypt, for example, watercourse-related data are classified as a national security issue. See Goldenman, G., "Adapting to climate change: a study of international rivers and their legal arrangement”, 17 Ecology Law Quarterly (1990), at 741-802.

${ }^{30}$ Ebbesson, J., "The notion of public participation in international environmental law" 8 Yearbook of International Environmental Law (1997), at 51-97. 
no need for an international army if there is no international court; no consent to judicial determinations until there are common norms of international behaviour; no agreements on norms until nations with different values develop mutual confidence and a will to compromise in order to enhance the security and the well being of all peoples. Progress must be made in all areas if effective international law enforcement is to become a reality. ${ }^{31}$ (Emphasis added)

This is a key approach to international law and international legal order, in that it aims at the well-being of all peoples by securing an order of social justice. This, in essence, illustrates the interconnection between cause and effect, with emphasis on the root reasons rather than on the consequences. For instance, a state striving for security through military power will acquire stockpiles of arms, which may trigger an arms race among rival powers. The end result is that the original goal of security has been undermined in the process. Thus, of all the problems of the present world, the prevalence of military power positions ${ }^{32}$ dictating treaty terms is the main hindrance to fair international resource sharing. Because of this, treaty negotiations between riparian States and the terms of treaties between those States are often not based on their actual needs. ${ }^{33}$ This omission points to the need for a fundamental questioning of the military/arms-based security of States. Indirectly, this issue was addressed by the 1972 UN Declaration on Human Environment. Whether the signatories to (and those who drafted) the Declaration's Principle 21 were aware of it or not, the legality of the international sale of arms can be challenged. Principle 21 provides for States the sovereign right to exploit natural resources within their territory. At the same time, it prohibits States from causing damage to the human environment of other States. By implication, the use of natural resources by a given state to produce arms (and the sale of those arms to other States), ultimately results in damage to the human environment, regardless of the stated purpose of such arms, for instance, for national defence. In addition, funds spent on arms are clearly subtracted from those spent on fulfilling basic human needs. According to one analyst, the combined military budgets, for example, of all of the South Asian countries in one year are equivalent to the sum needed to provide basic living costs for the entire world's population. ${ }^{34}$ In this context of misuse of resources, the key to global security is the rethinking of military science (i.e., the challenging of the use of science for destructive purposes) and the need for conversion of military industries to civilian use. $^{35}$

31 Freencz, B., Enforcing International Law A Way to World Peace, A Documentary History and Analysis (New York: Oceana, 1983), at 493.

${ }^{32}$ Principle 21 seems to be aimed at complete disarmament; see Principle 21 in Report of the United Nations Conference on the Human Environment, Stockholm, 5-16 June 1972, UN Doc. A/CONF.48/ 14.

33 See, for example, treaties between the United States and Mexico, between Egypt and Sudan, between China and the lower Mekong basin States, or between India and Bangladesh.

34 Stark, A., "Från bombfronten-ingetnytt", Svenska Dagbladet, 3 June 1998, at 16.

35 Barnby, F., New Statesman and Society, 31 January 1992, at 14-16. 
The call for mutual confidence and a will to compromise can be interpreted as relevant to a form of shared resource management that is based on social justice. In particular, mutual confidence stems from the perception of common norms governing the behaviour of States. ${ }^{36}$ This ideally leads to the negotiation of treaties based on actual needs. Under these conditions, the will to compromise among States would emerge, and the foundation for the rule of law can be established. Within this foundation, there can be equality before the law and equal protection of the law in the true sense.

\section{A THIRD-GENERATIONAL INTERNATIONAL INSTITUTION}

A third-generational global democratic institution is essential in order to establish a system of international justice, democratic peace and global common security. The League of Nations, established after World War I, was a first-generational international organization which allowed its Member States to use war to settle international disputes in certain circumstances. ${ }^{37}$ However, in no case did the League impose sanctions on those States instigating war. ${ }^{38}$ During the time of the League international conflicts were mostly over the territory of States. These were the classic or first-generational conflicts. The failure of the League is often linked to its failure in preventing the outbreak of World War II. Nonetheless, regarding the judicial settlement of dispute, the establishment of the Permanent Court of International Justice (PCIJ), presently known as the ICJ, is one of the important achievements of the League. This is the most civilized method of establishing peace and securing justice. However, the compulsory jurisdiction of the court has not yet been established.

The UN, established after World War II, represents a second-generational international organization, facing not only second-generational conflicts, e.g., conflicts of ideologies, sphere of influence, and control of raw materials, but also thirdgenerational conflicts creating global insecurity, i.e., global warming, increasing poverty, the depletion of environmental resources, and international terrorism. Various forms of injustice are breeding disorder, which is in turn creating violence at local, national, and international levels, finally leading to global insecurity. The existing methods of international dispute settlement are for the most part "ad hoc and

\footnotetext{
36 For example, one of the common norms of international behaviours may be to treat others as you would have them treat you, as opposed to 'you must do what I say, not what I do'.

37 Article 12 of the Covenant of the League of Nations, including amendments in force, published by the Secretariat of the League of Nations, at 7.

38 Poeggel, W., and E. Oeser, "Methods of diplomatic settlement" in Bedjaoui, Mohammed (ed.), International Law: Achievement and Prospects (Paris: UNESCO, 1991), at 534.
} 
opportunistic with little adherence to the rules or procedures provided in the Charter, or even in the rules of procedure." 39

Dissimilarly to the Covenant of the League, the UN Charter prohibits the use of force, recognizing territorial sovereignty and integrity, and the political independence of States. Intervention in the affairs of States is prohibited. However, according to the UN Charter, the use of force can be justified in the cases of selfdefence and the collective use of force by and through the decision of the Security Council. The main reason for the Security Council to fail to fulfil its responsibility from the very start is that it suffered from the Big Brother syndrome. ${ }^{40}$ Subsequently, it was handicapped by the power politics between the two super-powers, i.e., the two Big Brothers: the United States and the Soviet Union. After the fall of the Soviet Union, the Security Council became interventionist, acting as a supra-national authority and exercising power as an international executive, legislative, and judicial authority.

Under the UN Charter, the legality of the supra-national behaviour of the Security Council is highly controversial. ${ }^{41}$ A series of sanctions and wars against Iraq has also been highly controversial, raising doubt about the character and purpose of conflict resolution by the UN. The need for an effective global institution is perceived by all Member States, in preventing and resolving third-generation conflicts. The bitter reality regarding the UN reform, as explained by the former UN Secretary General Boutros Boutros Ghali, is that Member States do not know what they really want from the UN: "as a forum just to talk about international problems or an institution to solve the problems of the world". ${ }^{42}$

\subsection{A 3G General Assembly}

The UN General Assembly is the best-represented body that could be developed as an international consensus-building body, responding to global challenges, and it could be empowered as a multilateral (binding) treaty-making body. The Assembly could also be a centre for conflict prevention and post-crisis settlement, given the present trend of often referring conflicting issues among States to the General Assembly. It should, however, be noted that not all of the Member States of the General

39 Eagleton, C., International Government (New York: Ronald Press Company, 1957), at 519. Eagleton was one of the members of the draft committee of the UN Charter. Although his book was published in 1957, his arguments are still valid since there are no changes in ad-hocism and non-adherence to law in international dispute settlement.

40 Big Brother is Watching You (war is peace, freedom is slavery, ignorance is strength, two and two make five, god is power). See Orwell, G., Nineteen Eighty-Four (London: Penguin Books, Martin Secker and Warburg Ltd., 1989).

41 Harper, K., "Does the United Nations Security Council have the competence to act as a court and legislature?" 27 New York University Journal of International Law and Politics (1994), at 103157.

42 Boutros Boutros Ghali talking with the former British Foreign Secretary Douglas Hurd, in a BBC television programme called "Search For Peace", prepared by Douglas Hurd (1997). 
Assembly have democracy. It is, therefore, proposed here that a Super General Assembly (3G General Assembly) should be established out of the existing General Assembly; each State's membership and voting strength would be based on democratic credentials. ${ }^{43}$ Based on the minimum criteria, such as multiparty democracy, a free press, an independent judiciary, and the rule of law, the ICJ could help to define democracy when and if needed. No State would have the power of veto in the General Assembly of democratic States, and its resolutions would be binding rather than merely advisory, provided that those resolutions are approved by a two-thirds majority of the Member States. This arrangement could be expected to be helpful for the democratization of internal politics of the Member States; also, to enhance the principle of sovereign equality and international legitimacy. One can argue against and oppose the above proposed status of the Assembly as an international parliament, yet the fact remains that the Security Council is already behaving as such: however, without a mandate. Therefore, it would appear more logical to authorize the Assembly to perform the legislative function, and the Security Council, the executive function.

\subsubsection{Models of $3 G$ General Assembly}

A model for third-generation organizations proposed by some experts suggests the creation of several separate authorities in different functional areas along the lines of the International Sea-bed Authority, designed to regulate deep sea-bed mining. ${ }^{44}$ Another model can be the Antarctica Treaty Regime. For example, Articles X and IV of this latter treaty impose obligations on third States. According to Article X, each of the contracting parties undertakes to exert appropriate efforts, consistent with the UN Charter, such that no one party engages in any activity in Antarctica contrary to the principles or purposes of the present treaty. ${ }^{45}$ Yet another model can be the further development of the United Nations Environmental Program (UNEP), borrowing from the International Labour Organization (ILO) model, to provide the legislative outcomes for international agencies. The ILO networks provide labour dispute settlements between employers and employees (including governments), which is an instructive model of direct involvement of non-governmental organizations in setting standards. ${ }^{46}$

${ }^{43}$ Here the term "Member States having democracy" means those States which have at least a multiparty democracy, a free press, an independent judiciary, and the rule of law: in other words, no military or other dictatorships such as absolute monarchies.

${ }^{44}$ The United Nations Convention on the Law of the Sea, 10 December 1982, UNDoc.A/CONF.62/ 112, reprinted in $21 \operatorname{ILM}(1982)$, at 1261.

45 See, 402 UNTS 71; The treaty entered into force on 23 June 1961.

${ }^{46}$ Palmer, G., "New ways to make international environmental law", 86 AJIL (1992), at 259-283. His model is as follows: 1) A General Conference comprising all members is to be convened annually and more often if the Governing Council so decides. The conference shall consist of four representatives from each member; two shall be government delegates and the two others shall represent business and environmental organizations, respectively; 2) The Governing Council is to consist of forty people: twenty representing government, ten representing business, and ten representing environmental organizations; 3) The ability of the conference to set international environmental 
It is important to note that the independence, legitimacy and impartiality of a third-generational global organization will be questioned - just as the role and position of the Security Council is often questioned regarding conflict resolutions. This question mainly arises in connection with the respective financial contributions of certain countries, and in particular the dependency of the UN on the US. Article 19 of the Charter provides that:

\begin{abstract}
A Member of the United Nations which is in arrears in the payment of its financial contributions to the Organization shall have no vote in the General Assembly if the amount of its arrears equals or exceeds the amount of the contributions due from it for the preceding two full years. The General Assembly may, nevertheless, permit such a Member to vote if it is satisfied that the failure to pay is due to conditions beyond the control of the Member.
\end{abstract}

In a reformed Article 19 it could be stated that a financial obligation of the members of the third-generation international institution must be recognized. A logical option in this regard is that Member States should contribute a proportion of their annual defence budget for the management cost of the third-generation international organization. The rule of economic liability towards such an organization needs to be based on a wise assumption, i.e., the higher the financial contribution to a thirdgeneration international organization, the better the national and global security. Such a contribution would help to promote common security, thereby building a more sophisticated form of international security. This could be the thrust of the common security concept. However, it raises a fundamental question as to how to build a global order.

A need for a standing military force would be anticipated within a third-generational international organization, as it is realistic to assume the lawful use of force

regulations by a two-thirds majority of the vote cast by delegates present. The regulations would become binding without further action. There would also be provision for recommendation to be made to members; 4) A Director-General and staff of the International Environmental Office, to have explicit international responsibilities for educating people about global environmental problems and what they can do to help; 5) The office to have defined functions for gathering information and monitoring compliance, including verification of compliance with the regulations; 6) A thorough preparatory process, in which there is ample notice, thorough scientific and technical preparation, and consultation before regulations are made; 7) Formal provision for authoritative and widely representative scientific advice and papers to be available to the organization; 8) Detailed requirements for nations to report annually on action taken to implement agreed regulations. The environment and business representatives would be required to report separately from governments; 9) Provision for any member to be able to submit complaints regarding non-observance in respect of any other member to the International Environment Office; 10) Discretion of the Council to refer such complaints to a Commission of Inquiry for a full report. The Commission shall consist of three appropriate experts of recognized impartiality and be chaired by a lawyer. The Commission is to make findings of fact and rule on the steps to be taken to deal with the complaint and the time by which the steps must be taken. Refusal by governments to accept these findings are to be referred to the full conference; 11) Authority for the council to recommend measures to the conference to secure compliance when it is lacking. 
in certain circumstances. Thus, instead of trying to assemble a multinational rapid response contingent under the existing system, a quite lengthy and complex process, some experts have proposed that the UN needs a standing force to intervene in trouble-spots around the world. One proposed solution is to put together a contingent of professional soldiers. ${ }^{47}$ The democratic General Assembly could suggest to the Security Council where and how the force could be deployed. However, such a proposal raises challenges that many governments are reluctant to confront.

In addition to the task to define global threats and appropriate responses, a $3 \mathrm{G}$ General Assembly needs to concentrate on both the prevention of conflict and alternative conflict resolution.

\subsubsection{Conflicts prevention}

Regarding the prevention of international conflicts, the UN Charter offers guidance on how to use an early-warning information system to prevent the development of disputes. The preventive measures provided in the UN Charter are as follows.

The primary responsibility for prompt and effective action in the maintenance of international peace and security as well as consistent vigilance of conflict situations rests with the Security Council. ${ }^{48}$ The UN Secretary General has the responsibility for bringing any matters of international conflict to the attention of the Security Council. ${ }^{49}$ The General Assembly may also discuss any questions relating to the maintenance of international peace and security. ${ }^{50}$ The General Assembly may call the attention of the Security Council to situations likely to endanger international peace and security, ${ }^{51}$ and the Security Council may take provisional measures for dispute prevention. ${ }^{52}$ Similarly, the ICJ may indicate interim measures. ${ }^{53}$ All of these measures provided under the Charter may be used even for the so-called 'global watch' ${ }^{54}$ So far, none of the above-mentioned measures seems to have been used in a timely or adequate manner.

Although the set of preventive measures is a farsighted arrangement of the UN Charter, neither of its organs seems to be accountable for their execution, nor have the Member States given a clear mandate or funds for the implementation of such

\footnotetext{
47 Brian Farrel, a military historian, and Christopher Lingle, an economist, wrote "Gurkhas could do the job" in International Herald Tribune, stating that the UN needs a minimum of 5,000 standing force, and the most suitable troop could be the Gurkhas, particularly since with the return of Hongkong to China in 1997, they will no longer be required in the British army. The Kathmandu Post (20 October 1994) republished the article, resulting into an interesting discussion, see <http:// library.wustl.edu/ listmgr/tnd/0067.html>(accessed 28 February 2006).

48 Article 34 of the UN Charter.

49 Article 99 of the UN Charter.

50 Article 11(2) of the UN Charter.

51 Article 11(3) of the UN Charter.

52 Article 40 of the UN Charter.

53 Article 41 of the ICJ Statute.

54 Ramcharan, B., The International Law and Practice of Early-Warning and Preventive Diplomacy: The Emerging Global Watch (Dordrecht/Boston: Nijhoff, 1991), at 22.
} 
measures. It has often been pointed out that the UN does not possess the necessary means, mandates and mission capacity to prevent the outbreak of hostility leading to devastating conflicts. Therefore, there is a need for a conflict prevention strategy, by which early warning systems could be improved through more effective, internationally co-ordinated efforts, while taking into account the economic and social root causes of the conflict. In order to avoid or prevent any conflict, it is necessary to understand the source of the conflict and design a process to deal with this source. For example, conflicts generated by data disagreement should be dealt with as soon as they arise. Conflicts of interest involve value differences or relationship issues; therefore, the psychological needs of the parties should to be addressed. In this situation, there is a dual function for the peace makers or peace keepers: one is to identify the cause of the conflict, and the other is to use appropriate alternative measures to prevent it. ${ }^{55}$

\subsubsection{Alternative Conflict resolution}

"Negotiate the interests rather than the positions." This is the concept of the Alternative Conflict Resolution (ACR). Attention to the traditional methods of diplomatic negotiation is given to the bargaining powers of the parties rather than to the actual needs of their respective populations. A study illustrates several benefits of using a combination of dispute resolution and decision analytical techniques to structure negotiations of environmental disputes. The interests of disputing parties are expressed in terms of a utility model, in which specific objectives with measurable criteria are used to evaluate how well alternative actions satisfy the goals. ${ }^{56}$

The ACR techniques are intended to facilitate consensus decision-making by disputing parties, thereby avoiding legal or administrative proceedings to resolve disputes. Some characteristics of this group of techniques include: 1) focusing on the underlying interests of the disputing parties, rather than on their bargaining positions; 2) using creative thinking to dovetail dissimilar interests, preferences, capabilities, risk tolerances, and to change disputes from being zero-sum games to situations with the potential for joint gains; 3) appealing to jointly-accepted objective standards for appropriating gains, and 4) requiring consensus among parties for decision, rather than majority rule. ${ }^{57}$ The concept of public involvement in dispute resolution is another form of ACR, and may be used to prevent disputes, resolve

\footnotetext{
55 Priscoli, J., "Public involvement; conflict management and dispute resolution in water resources and environmental decision making", 3-2/3 Water Nepal (1993), at 43-58.

56 Maguire, L., "Resolving environmental disputes: a framework incorporating decision analysis and dispute resolution techniques", 42 Journal of Environmental Management (1994), at 31-47.

57 These techniques are based on a socio-psychological approach rather than a purely judicial approach. An independent mediator is often used to direct the process of dispute resolution. The ACR techniques have been applied to policy disputes involving waste facility siting, national forest planning, and regulation of pesticides, among many others. All of the ACR techniques promote creative thinking and compromise, but they lack a formal structure for identifying critical sources of disagreement in complex disputes; here, decision analysis could provide a structure.
} 
them at earlier stage, or settle them prior to formal litigation. ACR involves six important concepts of public involvement, namely: 1) to build credibility; 2) to identify public concern value; 3 ) to develop consensus; 4) to keep parties informed; 5) to produce decisions, and 6) to enhance democratic practice. Within ACR, policy makers and the public have different roles from their traditional roles. ${ }^{58}$ Conflicts are classified along non-traditional lines. ${ }^{59}$

In order to find a solution to the above-mentioned cause of conflict, the following steps could be taken. Firstly, one must understand the source of the conflict then design appropriate public involvement and conflict management processes. Secondly, negotiation with an open mind and without any predetermined solution needs to take place. Thirdly, one must isolate extremes, such as the use of force or litigation. Fourthly, negotiation should be conducted around interests rather than around positions. Fifthly, durable settlement depends on at least three dimensions: procedural, psychological, and substantive satisfaction. Finally, it is necessary to employ techniques which help parties to talk directly with one another. It must be realized that negotiation of interest is not an easy task. Some conflicts need adjudication and others may require the use of force. The objective of ACR should not be to isolate adjudication, but to find settlement at an earlier stage.

\subsubsection{Creative thinking}

ACR requires creative thinking. It is impossible for all parties to think alike, but to act collectively in combating conflict and ensuring global security is possible. All problems may not be solved at once, yet a start would be made if States could agree on a common code of behaviours. This means that the perception of States may not be changed, while their role may be regulated. One of the major weaknesses in international conflict resolutions is the absence of consensual support for a transnational code of behaviour, such as that of 'do unto others as you would wish them to do unto you'. The prevention and settlement of third-generation conflicts mentioned above relates to third-generation rights and remedies - the collective human right to a human environment of sustainable development, which implies the right to life.

At present, there are many serious threats to common security created by competing power interests of States. The terror of the arms race and trade among States is still a vital issue to be resolved. In addition to this, there is at present a threat to environmental security, which cannot be achieved within the prevailing power interests of States. At the same time, a lasting settlement to any resource-related conflict cannot

\footnotetext{
${ }^{58}$ In doing so, all policy makers are considered not as one entity, but include elected, administrative officials of various types. The public is defined as the both formally organized and informally organized, and directly and indirectly affected public.

${ }^{59}$ It is generally understood that many of the international conflicts are based primarily not on fact, but on values. The types of conflict are: 1) conflicts of data;2) interest conflicts, or 3) conflicts of value differences. In most resource disputes, the primary cause of the conflict is rarely data. It is more likely to be caused by differing values, interests or, possibly, relationship issues.
} 
be found without environmental security. Thus, it is absolutely necessary to adopt the common security approach, and to take a step towards international dispute prevention rather than conflict resolution. There may be several options and a number of ways in which to ensure global security. First and foremost is the conversion of military industries to civilian purposes $;{ }^{60}$ second is the building of trust and confidence among States; third is the exchange of views and dialogue rather than confrontations and, last but not least, there is the priority of the common interests of humanity, rather than each State's pitting its national interests against others'.

\subsection{A 3G Court}

The contemporary world is (dis)organized in such a way that, from a legal point of view, States are independent of each other and have no actual authority over each other. Each State maintains its own courts and prescribes its own laws, often in isolation from other States. Unless bilaterally or multilaterally bound to each other by treaty to settle disputes or enforce judgments, States, especially powerful ones, often behave as if they are free selectively to recognize and enforce international judgments. States, in order to attain their political ends, place conditions, based on satisfaction of national interest, when acquiescing to international regulations.

The existing means and techniques of dispute settlement and conflict resolution can be viewed as two ends of a continuum, at one end being adjudication, i.e., arbitration and international courts, and at the other end being the possibility of the Security Council to use force as a means of securing international peace on the terms and conditions of the most powerful permanent member of the Council. In the field between the two ends of the continuum fall different kinds of non-judicial dispute settlement options like diplomatic negotiations or good offices.

Regarding the means of adjudication, the ICJ is an international institution with the necessary competence for the settlement of disputes ${ }^{61}$ including disputes related to natural resources shared or solely owned by states, but the Court is able to entertain a case only when the parties to the case have given their consent. ${ }^{62}$

60 Bamby, F., New Statesman and Society, 31 January 1992, at 14-16.

61 Jennings, R.Y., "The United Nations at fifty: The International Court of Justice after fifty years", 89 AJIL (1998), at 493-505.

62 GA Res.51/229, Annex (21 May 1997), UNGADoc.A51/869. According to Article 33(5) Subparagraph (i) to (vi) of the 1997 UN Convention on the Law of Non-Navigational Uses of International Watercourses, a compulsory fact-finding Commission may be requested under paragraph 1(b), which provides that unless the parties have agreed otherwise, the fact-finding shall be conducted by a factfinding Commission established in accordance with paragraph 1, subparagraph (b) of this article. See http://www.un.org/law/cod/watere.htm.

According to Article 36 (2) of the Statute of the International Court of Justice, the States which are Parties to the present Statute may at any time declare that they recognize as compulsory ipso facto and without special agreement, in relation to any other State accepting the same obligation, the jurisdiction of the Court in all legal disputes concerning: (a) the legal interpretation of a treaty; (b) any question of international law; (c) the existence of any fact which, if established, would 
A growing demand for a separate independent international environmental court led in 1993 to the establishment of the Environmental Chamber by the ICJ. ${ }^{63}$ This chamber resolved Naura $v$. Australia, settling on the payment of compensation by Australia, the UK and New Zealand; and the Chamber has also decided the Hungary v. Slovakia case ${ }^{64}$ In addition, the International Criminal Court has been established. The problem is that the Court has still not been recognized by the US. ${ }^{65}$

These examples exhibit that international judicial entities are capable of resolving third-generation disputes, provided that cases are referred to the court. However, it must be noted that the compulsory jurisdiction of the ICJ has not been universally recognized.

\subsubsection{Implementation of international law}

As there is no international public prosecutor to bring charges against States for the breach of law, the dispute settlement through the ICJ depends upon the balance of power and interests of States. In this scenario, the actors or subjects of international law often become divided, and vested interests prevail over human concerns and considerations of justice. An effective reaction of the international community to a conflict threatening international peace may be available only when the interests of the major powers, i.e., the five Permanent Members of the Security Council, are at stake.

In a conflict situation where the economic interests of the major powers compete, reactions are often divided. As a result, the UN in general, and the Security Council in particular, either ends up acting as an interventionist or remains inactive when it comes to conflict resolution. Lack of action is, in effect, an action, which appeases although this may not be intentional. Within this power scenario, there are obvious risks of a powerful State exercising pressure on a weaker one and thereby bypassing the law.

\subsubsection{Forced implementation: more problems than solutions}

The use of force is often said to be the last resort of the enforcement of international law. In this context, international law is currently facing a challenge. States involved in the invasion of Iraq seem to have taken the view that dictators, especially those involved in nuclear proliferation and/or supporting international terrorism, can be overthrown by the use of force. Despite the fact that no weapons of mass destruction were found and no link between the Iraqi regime and international terrorism has been established, the invading States are still suggesting that the dicta-

\footnotetext{
constitute a breach of an international obligation; (d) the nature or extent of the reparation to be made for the breach of an international obligation.

${ }^{63}$ Jennings, loc. cit., n. 61, at 493-505.

${ }^{64}$ Gabcikovo-Nagymaros Project Case, 1997, ICJ Rep.1997, at 1-72.

${ }^{65}$ Lack of recognition of this court by the most powerful members of the international community, the United States, illustrates the problems in establishing a third-generational organization.
} 
torial regime can be overthrown. There are also many States opposing such a view, taking a more legalistic approach to the enforcement of international law by preferring criminal prosecution against terrorists instead of the military use of force. The problem of the use of force for the enforcement of international law is that the military force can be used against a powerless, non-permanent member of the Security Council. There is no possibility that force could be used against a militarily powerful State. This is where the problem lies with the balance of power theory of international politics and the existing legal rules of the use of force. As to the non-compliance with the law by powerful States, the international public opinion may have very little impact, serving sanctions in response to the violation of international law.

When States behave in an uncivilized manner, leading to the violation of international law, what measures can be taken for the implementation? Is criminalization of international wrongdoing an option? Even if it be so, one has to be sure whether or not a deterrent theory of law and punishment works. These are vital issues of jurisprudence; actual implementation of international law depends upon the civilized behaviour of the State leaderships.

\subsubsection{Voluntary compliance of international law}

Voluntary compliance with international law is a civilized manner of its application to achieve legal justice, and global public opinion is a decent sanction of the law, influencing States' behaviour. The international legal system is built upon the principles of consent and reciprocity. International lawmaking through treaty or customary practice is based on the voluntary consent of States and adjudication is based upon the principle of reciprocity. By voluntary agreement, States may choose any avenue of international dispute settlement available under international law, including diplomatic (negotiation, inquiry, mediation, conciliation, good offices, Article 33 of the UN Charter) and adjudication, as well as arbitration. States may also enforce international judgements voluntarily. When and if necessary, States themselves impose sanctions upon each other, as there is no supranational authority to enforce international law. Enforcement of international law through the Security Council is also based on the consent rule. There are various kinds of sanctions available under international law, including so-called smart sanctions. However, the important question is: who uses sanctions against whom? It is vital to have a clear legal understanding about when and how to use sanctions.

As actors of international law, States usually comply with international rules through self-interest. Compliance with a vast number of international rules, covering socio-economic, technical and cultural activities among States, illustrates the observation of international law. The interdependency of States as well as the ongoing interaction between various sub-States' communities are facts of global life, and suggests that there is observation of international law. There are, however, problems in the enforcement of international law concerning cross-boundary activities, including the enforcement of environmental regulations.

In the cyber age of fast communications, it must be realized that the world's public opinion is increasingly becoming an instrument that serves as sanction of law. 
When there is a violation or lack of compliance with the law, States face criticism from the international community through the mass media, requiring a proper reply and justifications. More often than not, States attempt to justify their actions, arguing that they are indeed upholding the law. The lack of legal justification is condemned not only by affected parties but also by the world public opinion. States do not want to face such condemnation, which means that the international public opinion serves as a sanction for a breach of the implementation of international law.

Some governments comply with the world public opinion, and others defy it and therefore become constraints for the enforcement of the law. This means that implementation of the law also depends upon the political ideology of the country's leadership of the time. It is generally assumed that a democratically elected leader would listen to the world public opinion more closely than would a dictator.

At a time when the UN system is under consideration for change, the creation of a Super General Assembly of democratic States can be a futuristic solution to the problems facing international law, empowering the Assembly and guiding appropriate sanctions for the enforcement of international law on a case-by-case basis. This would help not only to enhance the system of legal justice, but also to establish social justice.

\section{CONCLUDING REMARKS AND SUGGESTIONS}

The Security Council has become a non-functional organ of the UN partly because of an absurd legal arrangement of it both as a legislature and a court, and partly because of a tendency towards unilateral intervention taken by a few powerful permanent members of the Council, such as intervention by the US and the UK over Iraq. Because of this particular intervention the legitimacy of the Council has been severely undermined. Since the credibility of the determination of global threats and appropriate responses to threats by the permanent members of the Council is questionable, global security cannot be realized by the enlargement of the Security Council. Instead of enlargement, a Super General Assembly needs to be created and empowered, and the ICJ needs to be strengthened. The separation of powers between the proposed Super General Assembly, the Security Council and the ICJ is vital for the establishment of the rule of law. This means that the transformation of the UN into a third-generational international institution is becoming increasingly important with the emerging notion of trans-boundary States, sharing sovereignty across State boundaries.

It is not that State boundaries are disappearing and national security has become irrelevant, but that important changes are taking place, such as an increase in global social movements and a growth in the recognition of a global common interest of social justice. All of these factors are transforming the classic national interests into one global interest. This development is taking place among global common masses, rather than on an inter-governmental level. Therefore, it is essential to strengthen a bottom-up approach to security in consistency with all kinds of threats (nuclear weapons and terrorism, genocide, famine, poverty, civil wars, and global climate 
insecurity created by unsustainable development), and not just with regard to selected threats defined by the powerful States. Global security should not only be left to be defined on the terms and conditions of the powerful permanent members of the Security Council; enforcement actions should not be left to their will. Given the background of problems as presented above, the following suggestions need to be taken into consideration although they may be controversial.

Instead of reforming the UN Security Council, which is unlikely to be reformed, it is appropriate to establish a Super General Assembly of democratic States with the power only to generate an international legal order. The member States of the General Assembly should be obliged to provide a compulsory progressive economic contribution to the UN at a fixed proportion of their yearly defence budget. The voting power and methods of the proposed Super General Assembly can be resolved through negotiation.

The role of the ICJ should be strengthened, especially through recognition of the compulsory jurisdiction and a unilateral right of States and sub-state entities to bring cases to the ICJ. The establishment of regional branches of the ICJ should be considered.

Extend the jurisdiction of the ICJ to entertain public interest litigations. Particularly in cases where there is a denial of justice or where a State judicial system fails to ensure basic human rights, the sub-State communities should be entitled the right to judicial remedy by and through the ICJ.

Enforce the ICJ's decisions, when and if needed, through the use of sanctions and force, with a majority decision of the proposed Super General Assembly, for which the existing Security Council will be obliged to fulfil its primary responsibility through the use of force. This will be a test of the will of the permanent members of the Council as well as demonstrating on whose terms security is perceived and for what purpose force is used. 